SJ Quinney College of Law, University of Utah Utah Law Digital Commons

Utah Law Faculty Scholarship

Utah Law Scholarship

$2-2017$

\title{
Emerging Shadows in National Solar Policy? Nevada's Net Metering Transition in Context
}

Lincoln L. Davies

S.J. Quinney College of Law, University of Utah, Lincoln.Davies@law.utah.edu

Sanya Carley

Indiana University Bloomington - School of Public and Environmental Affairs

Follow this and additional works at: https://dc.law.utah.edu/scholarship

Part of the Environmental Law Commons, and the Natural Resources Law Commons

\section{Recommended Citation}

Davies, Lincoln L., Carley, Sanya, Emerging Shadows in National Solar Policy? Nevada's Net Metering Transition in Context The Electricity Journal, Vol. 30, pp. 33-42 (Jan.-Feb. 2017).

This Article is brought to you for free and open access by the Utah Law Scholarship at Utah Law Digital Commons. It has been accepted for inclusion in Utah Law Faculty Scholarship by an authorized administrator of Utah Law Digital Commons. For more information, please contact 


\title{
Emerging Shadows in National Solar Policy? \\ Nevada's Net Metering Transition in Context
}

\author{
Lincoln L. Davies ${ }^{*} \&$ Sanya Carley ${ }^{* *}$
}

\begin{abstract}
Nevada recently overhauled its net energy metering policy, and instituted a new net billing program in its place. Nevada's decision received significant attention across the nation, and raised the question whether other states will follow suit. This article reviews the process and decisions in Nevada that led to these policy changes, and puts Nevada's experience in the context of national solar industry and net metering policy trends. Observing that pressure to change net metering policies is likely to increase across the U.S., the article concludes with insights that other states can glean from Nevada's experience.
\end{abstract}

Keywords: Net energy metering, solar photovoltaic, distributed generation, Nevada

\footnotetext{
* Associate Dean for Academic Affairs, James I. Farr Professor of Law, and Presidential Scholar, University of Utah S.J. Quinney College of Law.

${ }^{* *}$ Associate Professor, School of Public and Environmental Affairs, and Chair, Policy Analysis and Public Finance Faculty Group, Indiana University. This article is derived from Sanya Carley \& Lincoln L. Davies, Nevada's Net Energy Metering Experience: The Making of a Policy Eclipse?, Report for Brookings Inst., Brookings Mountain West (November 2016), some portions of which appear herein.
} 


\section{Introduction}

In December 2015, the Nevada Public Utilities Commission (PUC) issued its muchanticipated net metering decision. Nevada's PUC chose to restructure the way that net metering functions in the state. It decreased the amount of compensation offered to homeowners and businesses using rooftop solar and imposed heavy charges on them for their use of the electricity grid.

Immediately, stakeholders asked whether Nevada's decision was a harbinger of more changes to come. As one observer noted, Nevada's decision "turned ratemaking into national news," and raised the question whether "other states follow in [Nevada's] footsteps" (Pyper, 2016)? The question is legitimate. Does Nevada's overhaul of its policy mark the beginning of the end for net metering in the United States?

For decades, net energy metering, or "net metering" (NEM), has served as the leading state-level policy to promote distributed solar energy in the United States. Shortly after Congress passed the Public Utility Regulatory Policies Act of 1978 (PURPA), states began using net metering to encourage rooftop solar and other small-scale energy applications. Ever since, a hallmark of these laws has been their provision of a credit — at the full retail rate of electricityfor excess energy produced by photovoltaic (PV) panels and other qualifying equipment. It is accepted in the literature that this fiscal compensation is what makes NEM laws effective at promoting small-scale solar resources (Baker-Branstetter, 2011; Del Chiaro and Gibson, 2006). The decision, then, of one of the sunniest states in the Union to remove this fundamental feature of its net metering law garnered instant attention from the media, the solar industry, and state policymakers.

Of course, Nevada's shift away from traditional net metering did not occur in a vacuum, and an understanding of other ongoing market and policy trends is necessary to put Nevada's decision in context. It is a considerable understatement to note that the primary trend in the solar energy industry over the last decade has been one thing: change. On the heels of Germany's — and 
other countries' - pioneering policy efforts, and China's burst onto the PV manufacturing scene, solar module prices have plummeted while installations have skyrocketed. In 2015 alone, the world added $50 \mathrm{GW}$ of PV capacity, increasing the aggregate total to $227 \mathrm{GW}$ - up from a mere 5.1 GW only ten years earlier (REN21, 2016).

This remarkable growth has also been driven by various renewable energy policies around the world. As of 2016, 173 countries have renewable energy targets; more than 100 nations have adopted feed-in tariffs; another 100 jurisdictions employ renewable portfolio standards (RPSs) or quota mechanisms; and 64 use tendering or competitive bidding to encourage renewable energy use (REN21, 2016). Thus, it is not simply the solar industry that is evolving but the policy landscape that shapes it as well.

The consequences of this shifting policy environment for the solar industry are complex. Governments are offering increasingly more support for solar technology. More than 50 countries now have different varieties of net metering policies. In the United States, 41 states plus the District of Columbia currently use some version of net metering (NCCETC, 2016c). Moreover, 22 states plus the District of Columbia have solar- or distributed generation-specific carve-outs or multipliers as part of their RPS policies (REN21, 2016). These numbers suggest that there is extensive support for solar PV both domestically and internationally, and that a primary way jurisdictions support small-scale PV continues to be through net metering.

Despite this widespread use of net metering, however, the shape of these laws is beginning to change. Of the 41 states that provide net metering in the United States, 10 now offer compensation at a level lower than the full retail rate of electricity. This estimate does not include Nevada or Hawaii, both of which have moved away entirely from traditional NEM (NCCETC, 2016c). These policy modifications are critical because it is well documented that one of the most important factors for promoting renewables is policy stability. Once policies begin to shift, as they have in other nations, industry often suffers, particularly if the shifts were unexpected, drastic, or retroactive in application (Davies \& Allen, 2014). In Nevada, for example, multiple 
solar companies significantly cut jobs and some left the state altogether after the PUC's decision to abandon its net metering law. In addition, those residential customers that formerly invested in solar PV with the expectation of utility compensation for decades were faced with the specter of having to transition to the new billing scheme.

What does Nevada's choice to abandon traditional net metering mean for the future of solar policy in the United States? We posit that falling solar prices across the globe are causing policymakers to question whether they need to revise their PV support programs. While some jurisdictions, including California and Colorado, so far have chosen not to follow Nevada's lead, it is possible that increasingly more states will consider abandoning their traditional NEM policies for ones that significantly reduce compensation and also impose new types of charges on PV customers. If this occurs, Nevada's decision eventually may be recognized as a turning point for how the United States uses policy to support rooftop solar. This transition, however, if it occurs at all, is bound to be messy — politically, legally, and economically — and managing how net metering laws evolve will be a key challenge for policymakers in years to come. Particularly important will be ensuring that policies are modified only on a prospective, not retroactive, basis, and that discussions about whether the policy should exist at all are kept separate from discussions about specific rate structures for PV customers.

We explore the changing world of net metering policy in this article by first detailing the experience in Nevada. We then place Nevada's experience in a broader context of other nationwide trends. Finally, we draw several insights from Nevada's experience that other states may consider as they deliberate the future of their own NEM programs.

\section{Nevada's Experience: From Net Metering to Net Billing}

In 2013, the Nevada Legislature passed Assembly Bill 428 (A.B. 428), which directed the Public Utilities Commission to evaluate "the comprehensive costs of and benefits from net metering in this State" (Nevada Legislature, 2013). This charge came in direct response to the rapidly growing solar industry in Nevada. By 2013, more than 3,000 customers had enrolled in 
the net metering program of the state's primary utility, NV Energy, with 50 of the $60 \mathrm{MW}$ in the program sourced from solar (E3, 2014). Projections at the time anticipated that another $234 \mathrm{MW}$ of net metering capacity—nearly four times the existing amount—would be added in just the next three years (E3, 2014; Friedman, 2014). Moreover, by 2014, Nevada had spent \$185 million in incentives to promote solar power (Saunders, 2014).

\section{The E3 Cost-Benefit Study}

To assess the value of net metering in Nevada, the PUC engaged Energy + Environmental Economics (E3) to conduct a benefit-cost analysis. E3's study evaluated costs and benefits of net metering across all potential societal impacts and reached five core conclusions. First, NEM in Nevada creates a net present value benefit of roughly \$36 million for NV Energy's non-NEM ratepayers. Second, on average, NEM users in Nevada pay about $\$ 0.02 /$ kilowatt-hour $(\mathrm{kWh})$ more for electricity than non-NEM users, which creates a net cost of about $\$ 135$ million over the 25-year lifetime of those users' systems. Third, before 2014, net metering increased Nevada utility bills slightly. However, going forward, NV Energy bills should "decrease substantially" due to net metering, on the order of \$716 million for PV systems installed through the year 2016 over their lifetime of 25 years. Fourth, net metering moderately increases electricity costs, by about $\$ 0.02 / \mathrm{kWh}$, due primarily to the lower cost of utility-scale solar compared to distributed solar. Fifth, including societal benefits in the calculation "does not significantly" alter E3's other conclusions, primarily because Nevada has a 25 percent renewable portfolio standard $(\mathrm{E} 3,2014)$.

These findings were noteworthy. They showed that net metering generally benefits the state, including customers who do not participate in the program. However, E3 observed that all of these estimated benefits depend in part on Nevada's RPS, which affords substantial additional compliance credit to rooftop solar. If that credit is removed, the benefits of net metering diminish, and the costs rise. Likewise, E3 determined that altering electricity rates would shift how NEM's benefits are distributed. If rates include higher fixed (system) costs and lower variable (energy) 
costs, net metering's benefit to non-NEM users would increase from $\$ 36$ million to $\$ 95$ million. And, if E3's assumed cost of $\$ 100 / \mathrm{MWh}$ for utility-scale solar decreased to $\$ 80 / \mathrm{MWh}$, "the overall economic proposition of NEM" would change (E3, 2014).

\section{Further Legislative Action: S.B. 374}

Though parties had some criticisms, the E3 study was generally well received, both by the public and among interest groups. The Nevada PUC adopted it and issued a report to the state legislature based on its findings (Nevada Public Utilities Comm'n, 2014a; Nevada Public Utilities Comm'n, 2014b).

In response, the legislature passed another net metering law, one that this time called for action and not just evaluation. Senate Bill 374 (S.B. 374), which became law on June 5, 2015, decreased the cap for net metering in Nevada from 3 percent of statewide peak generation capacity to $235 \mathrm{MW} .{ }^{1}$ The law also empowered the PUC with new authority to "establish one or more rate classes for customer-generators" (Nevada Legislature, 2015). Further, S.B. 374 forbade the PUC, after the $235 \mathrm{MW}$ cap was met, from approving NEM tariffs that "unreasonably shift costs from customer-generators to other customers of the utility" (Id).

At the time of passage, Nevada's Governor, Brian Sandoval, praised S.B. 374 as a "compromise measure that will allow the rooftop solar industry to continue to create jobs and grow in Nevada while protecting non-solar ratepayers" (Office of the Governor, 2015). Others, however, were not so optimistic. Solar companies had sought an increase, not a decrease, of Nevada's net metering cap, and public demonstrations were held in favor of that proposal (Page, 2015). As it actually played out, the 235 MW cap, which was supposed to provide solar companies with certainty at least through 2015 , was maxed out less than two months after S.B. 374's passage, which in turn precipitated an effort from NV Energy to overhaul Nevada's net metering program altogether (Pyper, 2015).

1 Peak capacity that year was 10,485 MW (U.S. EIA, 2016). 


\section{The Overhaul of Net Metering in Nevada}

On July 31, 2015, NV Energy filed a new tariff with the PUC seeking to fundamentally alter net metering in the state. This filing sought three core changes. First, it requested creation of a separate customer class for NEM as S.B. 374 anticipated, distinguishing these ratepayers as "partial requirements" customers. Second, NV Energy proposed implementing a new pricing scheme, namely, "time of use" (TOU) rates. Third, and most importantly, NV Energy sought a new and different net metering compensation scheme. Rather than crediting NEM customers with the full price of retail electricity, NV Energy sought to impose a much different, three-part rate schedule: 1) a high, solar-specific service charge for fixed costs; 2) a demand charge for distribution costs; and 3) an energy charge.

In support of its rate filing, NV Energy did not rely on the E3 Study. Rather, it submitted a marginal cost of service study (MCSS) as it would with a regular rate filing. NV Energy thus suggested that the E3 study was irrelevant in the proceeding: "A cost-benefit study does not estimate marginal costs or prices of any kind... [I]t focuses on whether a specific investment, policy or program is desirable or not" (NV Energy, 2015).

NV Energy's filing marked the start of a contentious, heated proceeding. Numerous parties took issue with its proposal, lodging a wide range of complaints. Several parties attacked both the concept and specifics of NV Energy's MCSS analysis. Others urged the Commission to consider the E3 study. The PUC's Regulatory Operations Staff suggested NV Energy's filing be rejected, on the grounds that it is inappropriate to create new rate classes between general rate cases. Finally, many parties urged the PUC to grandfather existing NEM customers so that NV Energy's proposal would not apply to them. In fact, NV Energy itself initially argued for this approach, although later in the proceeding it switched its stance and opposed grandfathering (Nevada Public Utilities Comm'n, 2015).

Despite the wide-ranging opposition to NV Energy's proposal, the Nevada PUC largely approved it, and created a new and different net metering regime. Because NV Energy's proposal 
was so different from traditional NEM, many observers began referring to it as something different entirely_- "NEM 2.0" or "net billing." Both names carried significance. The idea of "NEM 2.0" conveys the idea that traditional net metering was now a dead letter in Nevada. And the moniker "net billing" was appropriately descriptive because the new program only credits NEM customers at the wholesale avoided cost of energy, not the fully bundled retail price.

Also significant was the way the PUC reached its decision. The PUC found NV Energy's MCSS consistent with its rate filing practice. It also determined that NEM ratepayers should be put in a new, "partial requirements" rate class, because their usage profiles differ on an hourly basis from non-NEM customers so the cost of serving them is different as well. This, the Commission said, corrected an unfair subsidization of solar users by non-NEM customers: "On average, the resulting shift in cost responsibility is approximately $\$ 623$ and $\$ 471$ for each single family residential NEM ratepayer annually for NPC and SPPC, respectively. The magnitude of this cost shift is unreasonable." (Nevada Public Utilities Comm'n, 2015).

The Commission also rejected the notion that the E3 study should be used to establish net metering rates. Although the E3 study found that net metering provided non-NEM customers with a \$36 million benefit, the PUC said that the MCSS showed a \$9 to \$114 per month subsidy from non-NEM customers to NEM customers. Further, the Commission reasoned that the E3 study's finding of net benefits was undermined by a recent power purchase agreement that NV Energy had entered into for \$50/MWh, when E3 had assumed a cost of \$100/MWh (Nevada Public Utilities Comm'n, 2015).

Nor was the PUC persuaded by requests to grandfather existing NEM customers - or that its decision was likely to hurt the solar industry. On the first point, the Commission said there was "no difference" between old and new NEM customers in terms of NV Energy's costs of service (Nevada Public Utilities Comm'n, 2015). It was true, the Commission acknowledged, that "[e]vidence presented in these proceedings suggests that the small-scale (rooftop) solar vendors . . . failed to inform ... customers of the potential changes to the old NEM rates as contemplated by 
SB 374." (Id.) Nonetheless, the PUC found this immaterial because "[a]ll investments come with risk," and "[a]ll ratepayers . . . bear the risks and rewards of making investment decisions ... with the knowledge that electric rates and tariffs can change at any time ...." (Id.) Consequently, the Commission ruled that it would not use grandfathering in NEM 2.0: "Non-NEM ratepayers should not be asked to act as a safety net to fund the unreasonable cost shifts needed to guarantee a return on NEM investments." (Id.)

On the second point, the PUC called the "exodus of small-scale (rooftop) solar vendors" from the state "unfortunate[]" but said it reflected their "short-sighted business strategy that is harmful to the long-term viability of solar energy" (Nevada Public Utilities Comm'n, 2016b). Solar companies in Nevada, the PUC reasoned, had long been the beneficiaries of not one but two subsidies — the first, net metering payments at "a full-requirements rate structure," the second, “rebate[s] through the [state's] SolarGenerations program [that] ... has been in place for over a decade" and "will total \$255 million" over time. (Id.) The PUC thus suggested that the new NEM 2.0 program would create "a glide path" for the solar industry, eventually delivering it "toward self-sustainability in Nevada" (Id.).

“NEM 2.0"

NEM customers, however, were not nearly as sanguine about the idea of NEM 2.0. Although the PUC announced that the new net billing program would be implemented in five stages over twelve years, the policy modifications still presented a radical change. The PUC modified NV Energy's proposal to eliminate the suggested demand charge, but it approved almost all other aspects of NEM 2.0 as originally submitted. Specifically, NEM customers would now pay two charges: (1) an increased "basic" service charge for fixed costs, higher than what other retail customers pay; and (2) a volumetric rate for energy, less any energy produced. Importantly, under this volumetric rate, NEM customers no longer receive credit at the fully bundled retail rate of electricity, but rather, only the levelized avoided cost of energy. 
Together, these two changes substantially reduced compensation to Nevada's NEM customers. For instance, prior to 2016, NEM customers in NV Energy's northern service territory would have paid a $\$ 12.75 /$ month basic service charge and just over $\$ 0.11 / \mathrm{kWh}$ for electricity. They would also receive $\$ 0.11$ for every $\mathrm{kWh}$ of electricity they sent back to the grid. By the time the PUC's order takes full effect in 2028 , however, the same customer will pay a $\$ 38.51 /$ month basic service charge and roughly $\$ 0.10 / \mathrm{kWh}$ for electricity. However, when that customer sends power back to the grid, they will receive just over $\$ 0.02 / \mathrm{kWh}$ in compensation (Nevada Public Utilities Comm'n, 2016c). This roughly $80 \%$ reduction in NEM compensation fundamentally alters the economics of rooftop solar in Nevada. The PUC also ordered NV Energy to include a line item on every customer's bill for the amount of the "NET ENERGY METERING SUBSIDY" they pay each month (Nevada Public Utilities Comm'n, 2016a), presumably to draw attention to NEM customers.

\section{Aftermath: Swift Exit, Ongoing Discord}

Although the PUC's adoption of NEM 2.0 was final, it was not the last word in Nevada on net metering. The PUC's order immediately created strong reverberations throughout the state, many of which are still lingering.

Most prominently, the PUC's decision almost immediately pushed several PV companies out of the state. As of 2014, Nevada hosted a thriving solar industry. In that year, Nevada enjoyed the third highest rate of solar photovoltaic deployment in the nation, behind only California and Arizona, with approximately 2 TWh of solar generation (U.S. EIA, 2014). SolarCity, Sunrun, and Vivint Solar employed thousands of Nevada workers, with SolarCity alone opening an 18,000 square foot operations center and employing more than 900 people (Friedman, 2014). Following the PUC's decision, however, the state's solar industry quickly contracted. SolarCity announced that it would cease sales and installations in Nevada and relocate more than 550 jobs to "businessfriendly states" (SolarCity, 2016). Both Sunrun and Vivint Solar made similar declarations (St. 
John, 2016). Meanwhile, new solar installations dropped 92 percent in the first quarter of 2016 following the Commission's decision (Muro and Saha, 2016).

Given these economic impacts, it was perhaps inevitable that Nevada's net metering battle would play out publicly, and with perhaps unprecedented emotion. The solar industry repeatedly voiced its vehement opposition to the PUC's decision, in stark terms atypical of standard corporate press releases. As Robco Electric President, Rob Kowalczik, lamented, "The PUC made a decision and it just devastated our industry" (Brady, 2016). Sunrun—specifically singling out Nevada's governor-likewise expressed its deep regret at the policy shift:

Sunrun continues to be disappointed by the Nevada Public Utility Commission's decision to end net metering and refusal to grandfather existing rooftop solar customers. Following the Nevada PUC's decision, Sunrun closed its operations in Nevada. During those difficult times, statements were made that were not in the spirit of partnership that Sunrun has always intended to have with Governor Sandoval (Sunrun, 2016).

Celebrities, including Leonardo DiCaprio and Mark Ruffalo, rallied to the solar industry's aid, urging the PUC to reconsider its decision. Presidential candidates, including Hillary Clinton, chimed in via social media. (Fehrenbacher, 2016a; Fehrenbacher, 2016c). In a December 2015 speech, Bernie Sanders called the PUC's decision “just about the dumbest thing I have ever heard" (Lucas, 2015). Even the PUC itself entered the fray, with its Chairman, Paul Thomsen, criticizing solar companies in a high-profile interview in Fortune for "reprehensible sales tactic[s]," "ex parte communication[s]," and failing to "provide quantifiable evidence" because what they "really want[ed was] to have this debate in the media and outside of professional scrutiny." (Fehrenbacher, 2016b).

Still, as heated as the rhetoric was in the aftermath of the PUC's decision, the substantive debate was not over. Bowing to public pressure, NV Energy switched positions again and in July 2016 made a filing with the PUC asking that NEM customers who had submitted applications to 
interconnect prior to 2016 be grandfathered into the old net metering scheme. Meanwhile, Governor Sandoval reinstated the state's New Energy Industry Task Force, which swiftly recommended that the PUC grandfather preexisting NEM customers. ${ }^{2}$ In turn, on September 16, 2016, the PUC did just that. It unanimously ordered that over 30,000 pre-NEM 2.0 customers would continue to receive original NEM rates (Fehrenbacher, 2016c; Hidalgo, 2016). Meanwhile, a state court found that the PUC had illegally forbidden grandfathering in the first instance (Maloney, 2016), and the Task Force went a step further, recommending that the state legislature consider a bill in 2017 that would "authorize a reasonable minimum bill structure as a compromise interim measure" while reinstating "retail rate net metering" as a way to "resurrect the residential and small commercial solar market in Nevada." (Nevada New Energy Task Force, 2016).

At all this, the solar industry quickly declared victory, while also vowing to continue to fight. As one industry spokesperson put it, "We now must put policies in place that support new solar customers in Nevada so that solar jobs can once again increase, and the robust economic activity associated with solar development can resume.” (Fehrenbacher, 2016c).

\section{Net Metering Under Fire-Broader National Trends}

It is tempting to characterize Nevada's experience as an anomaly, a cautionary tale about what can happen if net metering is not managed carefully. Nevada's choice to abandon traditional NEM, however, is actually part of a broader national trend that is rapidly emerging across the United States.

\section{Net Metering's Historical Context}

NEM first appeared in the United States in the early 1980s, and since then, nearly all states adopted some form of this policy. NEM has proved important in encouraging customerowned distributed generation (Carley, 2009; Carley and Browne, 2012). Over time, solar PV

\footnotetext{
${ }^{2}$ In addition, a citizen petition seeking to reverse the PUC's decision had been certified for the November election. However, a court enjoined that petition from being placed on the ballot, and on August 4, 2016, the Nevada Supreme Court affirmed that decision.
} 
deployment increased significantly as more states adopted NEM policies, particularly in recent years as solar prices also fell, financing options became more innovative, and jurisdictions adopted other policies to encourage solar deployment, including tax credits and RPSs (Darghouth et al., 2016). As of May 2016, one million solar installations operated within the United States. Highlighting just how quickly solar has evolved, the Solar Energy Industries Association predicts that the second million installations will be completed within two years, by 2018 (SEIA, 2016).

Prior to this solar boom, discussions about NEM policies tended to focus on the nuances of policy design (Bird et al., 2013). As installations have increased, however, the focus of these discussions has begun to shift—and broaden. In many jurisdictions, conversations have evolved to include the overall value of solar; the degree to which solar compensation accurately reflects the resource's value; whether NEM causes cross-subsidization between solar and non-solar owners; and whether NEM rate structures cause under-recovery of utilities' fixed costs (NC Clean Energy Technology Center, 2016a, 2016b; Bird et al., 2013). Despite the proliferation of such discussions, and several other activities as described below, most policymakers to date have decided against overhauling — or abandoning, as Nevada did—net metering. Yet, the mere fact that these issues are being raised suggests that U.S. solar policy is facing increasing scrutiny and, quite possibly, beginning to undergo a transition that breaks from net metering's historical importance.

\section{The Emerging Resistance to Traditional Net Metering}

So far, this transition has been manifested in three main ways. First, many states have produced or commissioned cost-benefit analyses of their NEM programs, similar to what Nevada did when it commissioned the E3 study. In 2015 alone, at least 24 states prepared formal benefitcost evaluations of solar and other distributed systems (Blackburn et al., 2013; NCCETC, 2016a).

An analysis of cost-benefit studies released to the public since 2013 reveals that their findings on solar energy's net value varies considerably. Estimates of net benefits range from $\$ 0.72 / \mathrm{kWh}$ to $\$ 33.60 / \mathrm{kWh}$, as demonstrated in Figure 1. This wide range is due to which types of 
costs or benefits are included in the analyses as well as the assumptions used to assess each type of cost or benefit. One of the major sources of differences across studies is whether the authors include the cost of the PV system to the owner. Nevada, for example, included this cost, which is particularly evident in the E3 study's large total cost estimate vis-à-vis other states' analyses.

Table 1 indicates the breadth of costs and benefits that can be included in a solar valuation study.

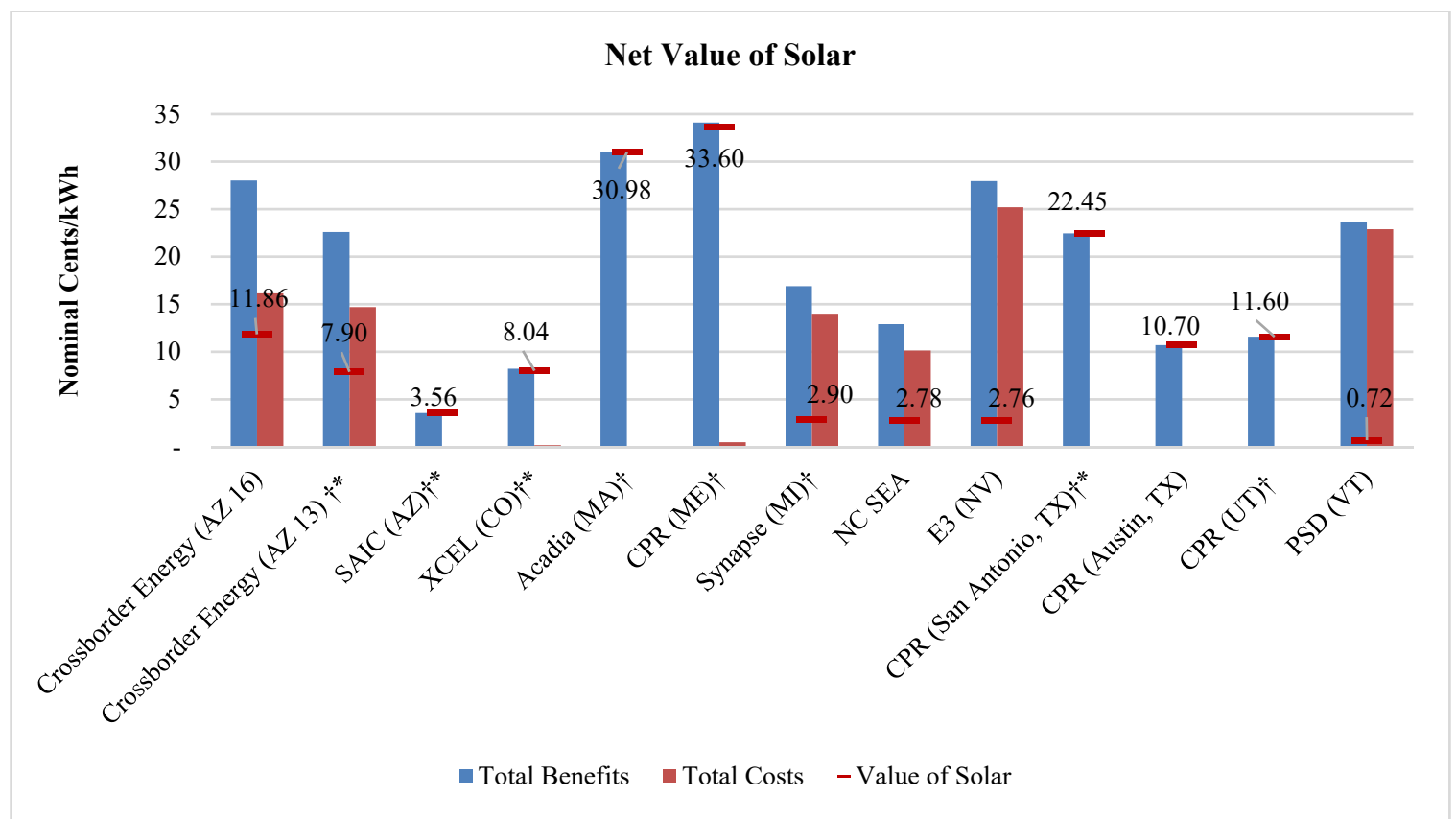

Figure 1. Benefits and Costs for State Solar Valuations with Publicly Accessible Data, 20132016

Table 1. Benefit and Cost Categories Used in Solar Valuation Studies

\begin{tabular}{|c|c|}
\hline Benefit and Cost Categories & Description \\
\hline Energy & Displaced need to generate energy from another source \\
\hline System Losses & $\begin{array}{l}\text { Energy that would have been lost through the transmission and } \\
\text { distribution (T\&D) system }\end{array}$ \\
\hline Generation Capacity & Deferred or avoided central generation capacity \\
\hline T\&D Capacity & Net change in T\&D infrastructure \\
\hline Grid Support Services & $\begin{array}{l}\text { Ancillary services required to enable reliable operation of } \\
\text { distributed solar }\end{array}$ \\
\hline Fuel Price Hedge & Offset utility cost to guarantee fixed electricity supply costs \\
\hline Market Price Hedge & $\begin{array}{l}\text { Difference in electricity and commodity prices due to lower } \\
\text { demand for energy }\end{array}$ \\
\hline Security & Change in grid reliability and resiliency \\
\hline Carbon & Reduced carbon emissions \\
\hline $\begin{array}{l}\text { Health and Criteria Air } \\
\text { Pollutants }\end{array}$ & Reduced criteria $\mathrm{NO}_{x}, \mathrm{SO}_{2}$, and particulate matter \\
\hline General Environmental & $\begin{array}{l}\text { Reducing water, land use, and value of displaced changes } \\
\text { planned to achieve the state's renewable portfolio standard }\end{array}$ \\
\hline Social & Net impact on economic development \\
\hline
\end{tabular}


Second, many states are considering redesigning the underlying architecture of their net metering programs. Such changes include modifications to the aggregate NEM program caps, often to increase them; changes to PV system size eligibility; and shifting the distribution of charges on consumers' bills from primarily variable to primarily fixed charges. Shifting fixed and variable charges in this manner can negatively affect NEM customers because they receive compensation for their PV generation based on the variable rate portion of their bill. During 2015 alone, 27 states took legislative or regulatory action in some way on their net metering policies.

Third, some states and other jurisdictions have considered adding new charges for solar PV owners, fundamentally altering their NEM compensation scheme, or implementing both changes. Solar charges are levied either based on a fixed dollar value, in variable amounts according to the customer's maximum electricity demand per month, or in tiers based on the size of the customer's PV system. Figure 2 and Figure 3 detail resolved proposals of this nature, as of mid-2016, displayed by utility. 


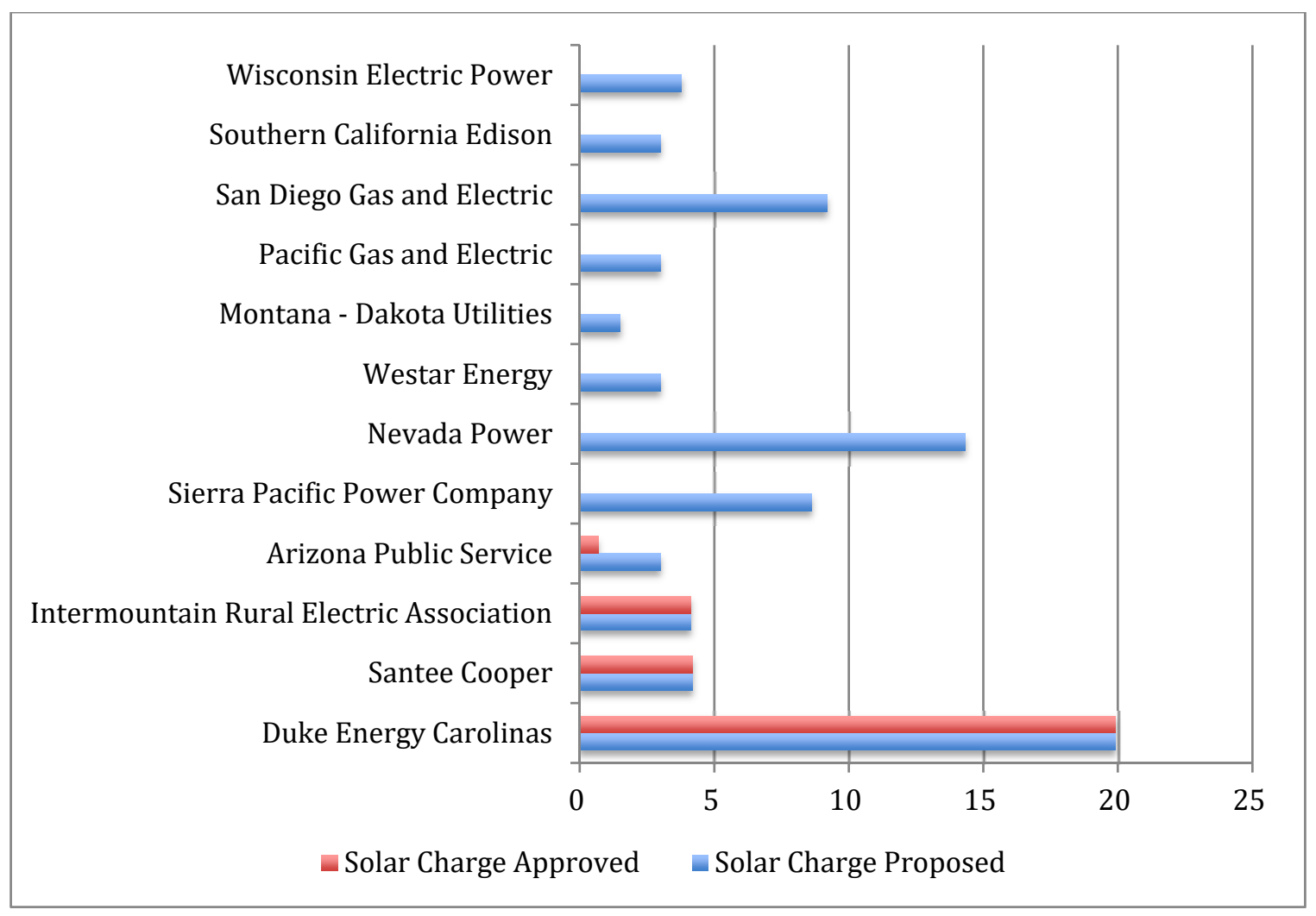

Figure 2. Variable Solar Charge Proposals, in $\$ / \mathbf{k W}$.

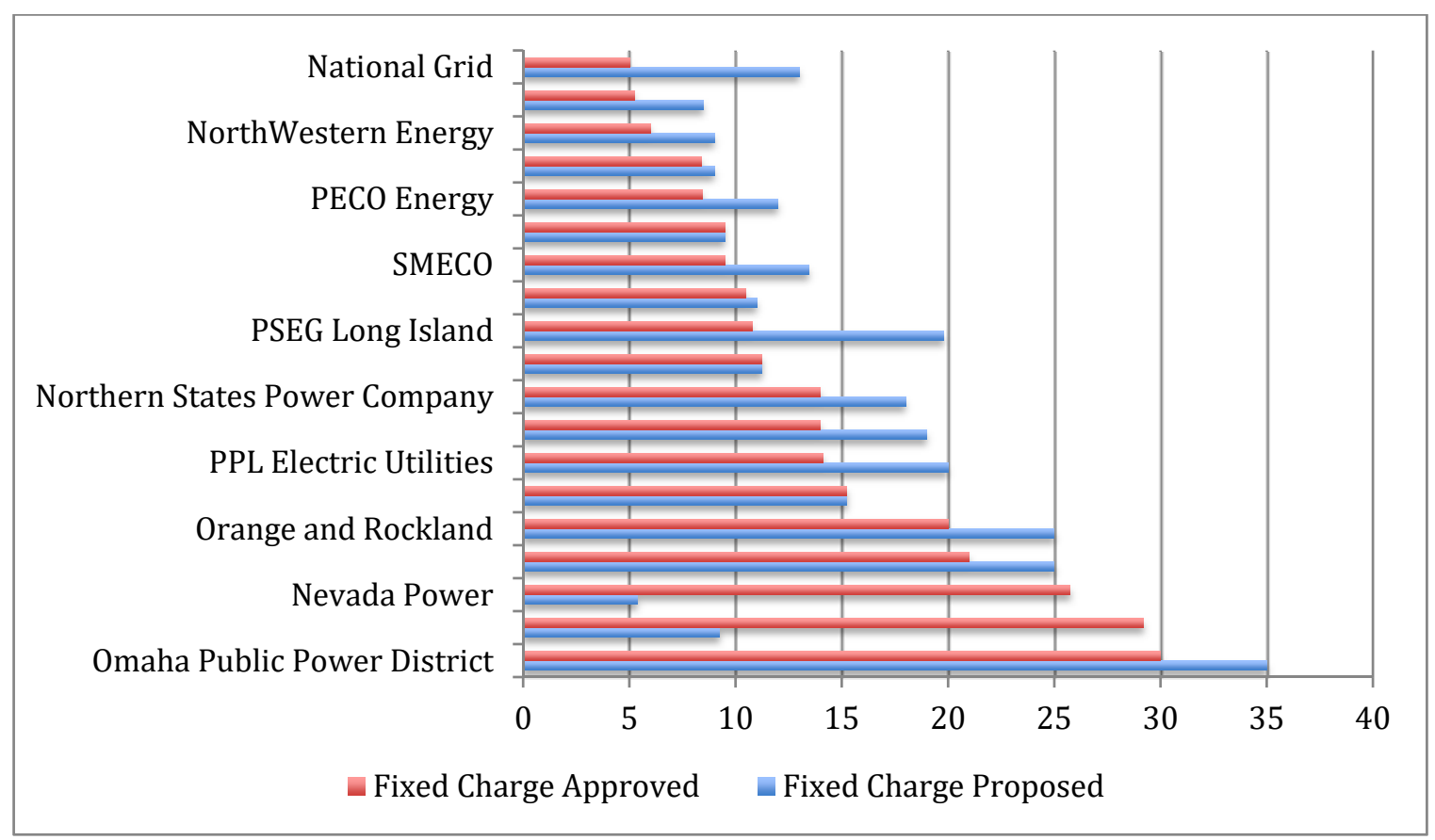

Figure 3. Fixed Solar Charge Proposals, in \$/month. 
Less common but growing in popularity are proposals to alter the price at which net metering is compensated, as happened in Nevada. These proposals too can vary, and have included movements to net billing like in Nevada, buy-all sell-all bidirectional rates, and other suggested changes. ${ }^{3}$ Most prominently, California and Colorado contemplated moving away from net metering and ultimately decided not to in recent years, but Hawaii chose to make the transition. Two utilities in Louisiana also recently instituted new billing schemes: one net billing and the other a buy-all, sell-all program. Arizona also has a net billing proposal under review, and Mississippi chose in 2015 to put net billing rather than net metering in place as its initial policy to promote distributed solar (NCCETC, 2016a)

These various trends suggest that state solar policies will become more diversified over time. As Figure 4 demonstrates, the nation's NEM map is already undergoing significant change, as four states that use these legal tools to promote rooftop solar now employ policies other than traditional net metering.

\footnotetext{
${ }^{3}$ For more detail on these alternative tariff designs, see Linvill et al. (2013), Bird et al. (2013), and Blackburn et al. (2013). For studies that compare the effects of different policy designs, see Darghouth et al. (2016) and Eid et al. (2014).
} 


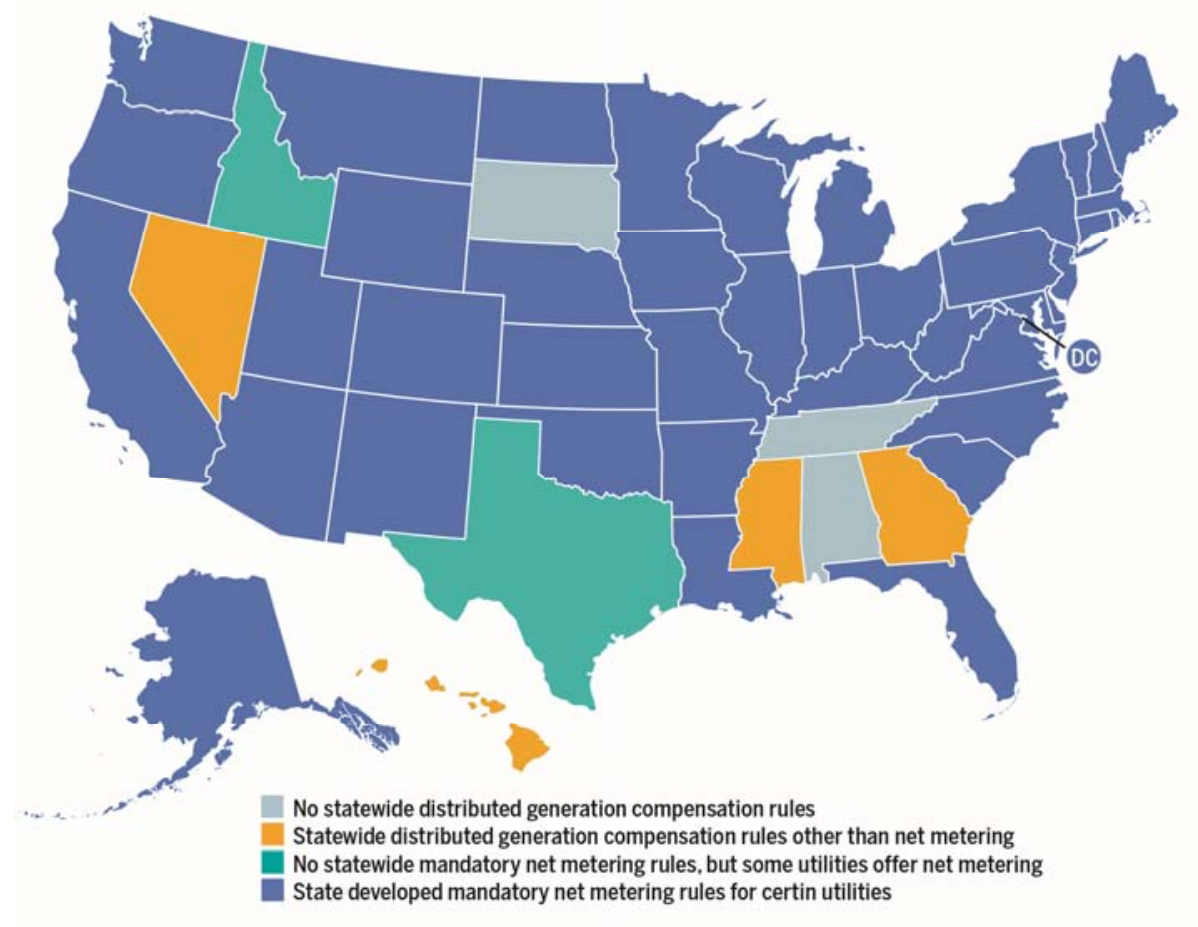

Figure 4. Status of States' Net Metering Policies as of March 2016

Adapted from NC Clean Energy Technology Center (2016)

Indeed, juxtaposition of recent changes to the net metering schemes in Nevada, Hawaii, and California provides insight into just how quickly NEM policies may begin to diverge from each other. Nevada, as detailed, adopted a net billing policy that imposes high fixed charges on NEM customers and compensates them at a rather low levelized avoided cost of wholesale energy. Hawaii also abandoned traditional net metering last year, but it replaced its regime with a different rate structure. In Hawaii, rooftop solar customers now can choose from one of two options: 1) a self-supply option in which customers earn retail rate credits for aligning their electricity consumption with actual solar generation but receive no compensation for any energy that is sent to the grid, or 2) a grid-supply option that is a net billing scheme crediting customers at the utility's avoided cost of $\$ 0.15$ to $\$ 0.28 / \mathrm{kWh}$, compared to the average retail rate of $\$ 0.38 / \mathrm{kWh}$ (Pyper, 2015b; Trabish, 2015). Under either option, residential PV customers who stay connected to the grid will pay a minimum bill each month of $\$ 25$. By contrast, California 
also adopted a supposed NEM 2.0, but its new policy is only slightly different than its former program. NEM customers in California still receive credit for PV generation at the retail price of electricity, but they now must use time-of-use rates as well as pay specific non-bypassable charges. The PUC also has vowed to revisit the program in 2019.

As these examples demonstrate, the breadth of ways that states can restructure their net metering programs is wide. What California, Hawaii, and Nevada have done is only the beginning, both in terms of the types of changes that are possible as well as the number of jurisdictions that may well head down the path away from traditional NEM.

\section{Mounting Pressure for Policy Change}

Nevada's and others' experiences reveal that there is mounting pressure to modify or abandon traditional NEM programs. Arguably, these trends are both a function of shifting political winds as well as fundamental structural changes in the solar industry. Just as utilities have gotten into the utility-scale PV game, they also have begun to push back against small-scale installations and the policy tools used to support them. In short, "Incumbent utilities have begun to fight net metering" (Eisen, 2014). Much has been made of the purported utility "death spiral," which theorizes that utilities might lose some business to "prosumers" like those using net metering, which in turn forces the utilities to spread costs across fewer customers, thus increasing prices, which itself encourages more customers to leave, and so on (Felder and Athawale, 2014). Whether or not this theory is accurate in reality, it provides a powerful narrative for the challenges that utilities today face, particularly because solar prices have fallen so precipitously and solar PV developments — both utility- and small-scale — have proliferated. It is thus unsurprising that utilities have begun to leverage their weight against policy schemes that promote distributed solar.

As solar expands, the limits on net metering programs are pressed. As noted, most NEM programs use aggregate caps on the number of energy systems that can qualify under the policy. Once these caps are reached, it necessarily raises the question of whether the existing policy 
should be changed. So far, many states have responded by increasing their caps, but others have stopped accepting applications for new net metering installations altogether. Others still, such as Nevada, take the opportunity once the cap is met to reassess the entire program and apply much broader modifications to the law (NCCETC, 2016a).

Most importantly, the confluence of these trends creates an environment that is ripe for solar policy change. Falling PV prices raise the question for some of whether policy support remains necessary. Utilities' efforts to push back against small-scale PV support mechanisms like NEM create political pressure on legislators and regulators to change these laws. And, the fact that NEM program caps are being reached gives utilities and others a procedural hook to start the conversation about whether and how those programs should be changed.

In short, the experience in Nevada was just one manifestation of this growing structural pressure on net metering, caused by a rapidly evolving solar industry. As the industry continues to change, such pressure is only likely to increase.

\section{The Future of Net Metering-Nevada as Outlier or Harbinger?}

Nevada's choice to abandon traditional net metering drew attention not only for its effects in the state but also for its potential national implications. While clear trends cannot be drawn from a single data point, even one as rich and complex as Nevada's experience reforming net metering, Nevada is not the only state that has revisited its NEM policy. What lessons, then, from Nevada's experience might other jurisdictions want to consider as they deliberate about their own NEM schemes - and the future of solar in their states? We argue that there are at least two important insights that can be drawn from Nevada's experience.

First, the legislative decision of whether to keep net metering should remain separate from the regulatory decision of what the details of a net metering program should be. Arguably, the Nevada legislature's passage of S.B. 374 was a de facto death knell for NEM, because it forbade any unreasonable cross-subsidization of NEM customers from other customers. However, rather than expressly announcing it was ending net metering, the legislature gave the PUC, an 
energy regulatory agency, the burden of answering the larger policy question of whether net metering should continue and in what form. Specifically, the PUC had to determine whether the E3 study — which had found that net metering provides significant net benefits in Nevada—could be used to decide the future of NEM. Of course, the PUC ultimately found the E3 study immaterial to the rate case before it, which should not have been surprising, since system-specific rate cases are a mismatch for assessing broader social benefits and costs (Davies, 2010; Wildermuth, 2010). The Nevada PUC acted in a way that is consistent with the charge of PUCs across the nation.

Nevada's experience thus underscores the need to keep decisions about whether net metering should continue separate from the design of a given program. From an institutional perspective, legislatures are best equipped to answer the first question; PUCs have comparative expertise on the second. Blending the inquiries, as arguably occurred in Nevada, presents difficulties.

In deciding to move to net billing, for instance, the Nevada PUC was forced to address the interaction between the state's RPS and any other policy it might use to support distributed solar. This consideration highlighted the tension in how Nevada promotes solar energy overall. The Nevada RPS expressly affords extra credit for small-scale, distributed solar, but S.B. 374 strongly intimated that existing NEM policies facilitating rooftop solar should be diluted. Of course, it is technically possible for expert agencies like the Nevada PUC to adopt rules that bridge competing legislative decisions such as these. But, at their core, such competing goals are actually policy tensions that are best resolved by politically accountable legislatures.

Indeed, if legislatures choose not to directly resolve the important question of whether to keep NEM programs at all based on net benefits and costs, and instead relegate that decision to a separate public authority that will almost certainly put the issue in the context of crosssubsidization, then the outcome in Nevada may be inevitable elsewhere as well. The Nevada PUC's rationale that NEM customers belong in a separate rate class because they use less 
electricity during the day and are thus "partial requirements" customers is far less reasoned decision-making rooted in logic than it is a simple observation of a self-evident taxonomy.

The real question, in other words, is not whether NEM customers are different from average retail customers; it is whether net metering should be used to support distributed solar energy. Legislatures might reach a variety of rational conclusions on that score, including possibly abandoning NEM altogether. A transparent process, however, will not obfuscate that question but will address it head-on.

In contrast to Nevada, for instance, California and Colorado both followed this more transparent process when they reexamined their own NEM programs and chose not to switch to net billing. In California, its PUC assessed the future of its NEM program under a legislative mandate to ensure that such tariffs reflect the "total benefits . . . to all customers and the electrical system.” (California Legislature, 2013). Similarly, in Colorado, the PUC opened an informational proceeding that included both a system-specific, cost-benefit study from the incumbent utility and a broader, socially focused analysis from a consulting group. Based on this more holistic record, the Colorado PUC eventually decided not to pursue further changes to NEM for the time being.

Second, net metering policies are likely to become more diverse across states over time and, as these policies evolve, it is critical to maximize policy stability, including by using - rather than abdicating - grandfathering for existing customers. Arguably, the most important change that Nevada made in its transition to net billing was its initial decision not to grandfather existing NEM users. Research has shown that one of the most crucial features of renewable energy support regimes is stability (Couture et al., 2010; Davies and Allen, 2014; Wiser and Pickle, 1998; Barradale, 2010). The Nevada PUC's original decision stood in direct contrast to this doctrine. The decision also did not align with conclusions drawn by other states, such as California and Hawaii, about the need for protecting those customers that made investment decisions under former policy regimes. 
Clearly, Nevada's original decision was particularly controversial, as evidenced by the political and social backlash that ensued. The resulting flap is arguably why the PUC chose to reverse its decision in September 2016. In fact, similar policy decisions not to grandfather existing customers when changing renewable support policies has proven problematic in a variety of contexts, including Spain (Davies and Allen, 2014). Such decisions unsettle the expectations of consumers, who, as residential ratepayers, tend to be less sophisticated than investor-owned utilities or merchant generators that devote their businesses full-time to buying and selling power.

In short, Nevada's experience with initially choosing not to grandfather customers in its transition away from NEM serves as a cautionary tale for other jurisdictions that may consider a transition of their own.

\section{Conclusion}

In the end, Nevada's choice to abandon net metering may raise as many questions as it answers. The decision makes clear that Nevada has, for now, chosen to take a different path than other jurisdictions in promoting solar power. Although net metering programs across the country are under fire, whether other jurisdictions will follow Nevada's lead—or whether they will choose paths more akin to California, Colorado, or Hawaii, or another path entirely-remains to be seen. On this important question, only time will tell, just as the world will continue to watch, keenly, developments as they further unfold in Nevada. 


\section{References}

Baker-Branstetter, S., 2011. Distributed Renewable Generation: The Trifecta of Energy Solutions to Curb Carbon Emissions, Reduce Pollutants, and Empower Ratepayers. Villanova Environmental Law Journal 22,1-29.

Barradale, M. J., 2010. Impact of public policy uncertainty on renewable energy investment: Wind power and the production tax credit. Energy Policy 38(12), 7698-7709.

Bird, L., McLaren, J., Heeter, J. Linvill, C., Shenot, J., Sedano, R., Migden-Ostrander, J., 2013. Regulatory Considerations Associated with the Expanded Adoption of Distributed Solar. National Renewable Energy Laboratory Technical Report, NREL/TP-6A20-60613.

Blackburn, G., Magee, C., Rai, V., 2013. Solar valuation and the modern utility's expansion into distributed generation. The Electricity Journal 27(1), 18-32.

Brady, J., 2016. Nevada Solar Power Business Struggles to Keep the Lights on, NPR.com, Mar. 11, 2016. http://www.npr.org/2016/03/11/470097580/nevada-solar-power-business-struggles-tokeep-the-lights-on (accessed 10/7/16).

California Legislature, 2013. Assembly Bill (A.B.) 327. https://leginfo.legislature.ca.gov/faces/billNavClient.xhtml?bill id=201320140AB327 (accessed 10/7/16).

Carley, S., 2009. Distributed generation: An empirical analysis of primary motivators. Energy Policy 37(5), 1648-1659.

Carley, S., Browne, T. 2012. Innovative US Energy Policy: A review of states' policy experiences. WIREs: Energy and Environment 00, 1-19.

Couture, Toby D., 2010. A Policymaker's Guide to Feed-in Tariff Policy Design, Nat'1 Renewable Energy Laboratory.

Darghouth, Naim R., Wiser, Ryan H., Barbose, Galen, Mills, Andrew D., 2016. Net metering and market feedback loops: Exploring the impact of retail rate design on distributed PV deployment. Applied Energy 162, 713-722.

Davies, L. L., 2010. Alternative Energy and the Energy-Environment Disconnect. Idaho Law Review 46, 473-507.

Davies, L. L., Allen, K., 2014. Feed-in Tariffs in Turmoil, West Virginia Law Review 116, $937-$ 1005 .

Del Chiaro, B., Gibson, R., 2006. Government's Role in Creating a Vibrant Solar Power Market in California, Golden Gate University Law Review 36, 347-391.

E3, 2014. Nevada Net Energy Metering Impacts Evaluation. Environmental Energy Economics, Nevada, USA: Environmental Energy Economics.

Eid, C., Guillen, J. R., Marin, P. F., Hakvoort, R., 2014. The economic effect of electricity netmetering with solar PV: Consequences for network cost recovery, cross subsidies and policy objectives. Energy Policy 75, 244-254. 
Eisen, J. B., 2014. An Open Access Distribution Tariff: Removing Barriers to Innovation on the Smart Grid. UCLA Law Review 61, 1712-1770.

Felder, F. A., Athawale R., 2014. The Life and Death of the Utility Death Spiral. The Electricity Journal 27, 9-16.

Fehrenbacher, K., January 14, 2016. Nevada's New Solar Fees Have People Furious. http://fortune.com/2016/01/14/nevada-solar-battleground/ (accessed 10/5/16).

Fehrenbacher, K., April 12, 2016. The Other Side of the Solar Firestorm in Nevada. http://fortune.com/2016/04/12/solar-firestorm-nevada/ (accessed 10/5/16).

Fehrenbacher, K. September 16, 2016c. Why Nevada Brought Back Favorable Rates for Existing Solar Customers. http://fortune.com/2016/09/16/nevada-solar-grandfathering/ (accessed 10/5/16).

Friedman, A. November 17, 2014. SolarCity sees bright, clean future in Las Vegas. Las Vegan Review Journal. Available at http://www.reviewjournal.com/business/business-press/solarcitysees-bright-clean-future-las-vegas (accessed 10/3/16).

Hidalgo, J., September 16, 2016. Nevada Regulators Unanimously Approve Rooftop Solar Grandfathering Deal. Reno Gazette Journal. http://www.rgj.com/story/money/business/2016/09/13/nv-energy-solarcity-deal-grandfatherresidential-rooftop-solar-customers/90306788/ (accessed 10/1/16).

Linvill, C., Shenot, J., Lasar, J., 2013. Designing distributed generation tariffs well: Fair compensation in the time of transition. Regulatory Assistance Project Report.

Lucas, S., December 28, 2015. In NLV speech, Sanders calls PUC solar decision 'just about the dumbest thing I ever heard.' Las Vegas Sun. Available here:

http://lasvegassun.com/news/2015/dec/28/in-nlv-speech-bernie-sanders-calls-puc-solar-decis/ (accessed 10/5/16).

Maloney, P., September 15, 2016. Nevada court overturns fixed charges, lower net metering rates for existing solar customers. Utility Dive. Available at: http://www.utilitydive.com/news/nevadacourt-overturns-fixed-charges-lower-net-metering-rates-for-existing/426302/ (accessed 10/7/16).

Muro, M., Saha, D. May 23, 2016. Rooftop solar: Net metering is a net benefit. Brookings Institute Advanced Industries Series Paper 91. http://www.brookings.edu/research/papers/2016/05/23-rooftop-solar-net-metering-murosaha\#.V0MctMHjazs.email (accessed 10/5/16).

Nevada Legislature, 2013. Assembly Bill (A.B.) 428. https://www.leg.state.nv.us/Session/77th2013/Bills/AB/AB428 EN.pdf.

Nevada Legislature, 2015. Senate Bill (S.B.) 374. https://www.leg.state.nv.us/Session/78th2015/Bills/SB/SB374_EN.pdf.

Nevada New Energy Task Force, 2016. Work Session Framework: New Energy Industry Task Force Policy Recommendations.

http://energy.nv.gov/uploadedFiles/energynvgov/content/Programs/Work\%20Session\%20Docum ent(2).pdf. 
Nevada Public Utilities Comm'n, 2014a. Net Metering Report, Docket No. 13-07010, Document ID No. 41397. http://puc.nv.gov/Dockets/Dockets/.

Nevada Public Utilities Comm'n, 2014b. Order, Docket No. 13-07010, Document ID No. 41448. http://puc.nv.gov/Dockets/Dockets/.

Nevada Public Utilities Comm'n, 2015. Order, Docket No. 15-07042, Document ID No. 8414. http://puc.nv.gov/Dockets/Dockets/.

Nevada Public Utilities Comm'n, 2016a. Modified Final Order, Docket No. 15-07042, Document ID No. 9688. http://puc.nv.gov/Dockets/Dockets/.

Nevada Public Utilities Comm'n, 2016b. Order on Reconsiderations and Rehearing, Docket No. 15-07042, Document ID No. 9686. http://puc.nv.gov/Dockets/Dockets/.

Nevada Public Utilities Comm'n, 2016c. Net Metering Rates and Rules. http://puc.nv.gov/uploadedFiles/pucnvgov/Content/Consumers/Be Informed/Fact Sheet Net Me tering.pdf.

NV Energy, 2015. Application of Sierra Pacific Power Company d/b/a NV Energy for Approval of a Cost of Service Study and Net Metering Tariffs, Docket No. 15-07042, Document ID Nos. 4402 and 4403. http://puc.nv.gov/Dockets/Dockets/.

North Carolina Clean Energy Technology Center (NCCETC), 2016a. The 50 States of Solar: 2015 Policy Review Q4 Quarterly Report. https://nccleantech.ncsu.edu/wpcontent/uploads/50sosQ4-FINAL.pdf.

North Carolina Clean Energy Technology Center (NCCETC), 2016b. The 50 States of Solar: Q1 2016 Quarterly Report, April 2016. https://nccleantech.ncsu.edu/wp-content/uploads/50-SoS-Q12016 Final.pdf.

North Carolina Clean Energy Technology Center (NCCETC), 2016c. Customer Credits for Monthly New Excess Generation (NEG) Under Net Metering. July 2016. http://ncsolarcenprod.s3.amazonaws.com/wp-content/uploads/2014/11/NEG-1.20161.pdf.

Office of the Governor, 2015. Sandoval Signs Additional Legislation into Law, June 5, 2015. http://gov.nv.gov/News-and-Media/Press/2015/Sandoval-Signs-Additional-Legislation-into-LawToday/.

Page, S., May 18, 2015. Nevada Solar Power Users Could Face New Fees This Summer. Think Progress. Available here: https://thinkprogress.org/nevada-solar-power-users-could-face-newfees-this-summer-a10f3882894a\#.t0s4145mj (accessed 10/1/16).

Pyper, J., 2015a. Conflict Over How to Value Solar Flares Up Again in Nevada. Greentech Media. http://www.greentechmedia.com/articles/read/Solar-Net-Metering-Conflict-Flares-upAgain-in-Nevada (accessed 10/5/16).

Pyper, J., 2015b, Hawaii regulators shut down HECO's net metering program, Greentech Media. https://www.greentechmedia.com/articles/read/hawaii-regulators-shutdown-hecos-net-meteringprogram (accessed 10/5/16). 
Pyper, J., February 4, 2016. Does Nevada's Controversial Net Metering Decision Set a Precedent for the Nation? Greentech Media. http://www.greentechmedia.com/articles/read/nevada-netmetering-decision (accessed 10/5/16).

Renewable Energy Policy Network for the $21^{\text {st }}$ Century (REN21), 2016. Renewables 2016 Global Status Report. http://www.ren21.net/wpcontent/uploads/2016/06/GSR_2016_Full_Report_REN21.pdf.

Saunders, M., July, 2014. Solar Energy in Nevada. Nevada Lawyer.

SolarCity, 2016. Following Nevada PUC's Decision to Punish Rooftop Solar Customers, SolarCity Forced to Eliminate More than 550 Jobs in Nevada. SolarCity Press Release, January 6, 2016. http://www.solarcity.com/newsroom/press/following-nevada-pucs-decision-punish-rooftopsolar-customers-solarcity-forced.

St. John, J., 2016. Nevada's Solar Jobs Exodus Continues, Driven by Retroactive Net Metering Cuts. January 8, 2016. Greentech Media. http://www.greentechmedia.com/articles/read/nevadassolar-exodus-continues-driven-by-retroactive-net-metering-cuts.

Solar Energy Industry Association (SEIA), 2016. Million Solar Milestone Factbook. Available at http://www.seia.org/sites/default/files/Million\%20Solar\%20Install\%20Factbook\%205.3.16.pdf.

Sunrun, 2016. Sunrun Statement on Lynn Jurich's Meeting with Nevada Governor Brian Sandoval, May 24, 2016. https://www.sunrun.com/why-sunrun/about/news/press-releases/sunrunstatement-lynn-jurich\%E2\%80\%99s-meeting-nevada-governor-brian.

Trabish, H. K., October 22, 2015. What comes after net metering: Hawaii's latest postcard from the future. Utility Dive. Available here: http://www.utilitydive.com/news/what-comes-after-netmetering-hawaiis-latest-postcard-from-the-future/407753/.

U.S. Energy Information Administration, 2014. Net generation by state by type of producer by energy source. https://www.eia.gov/electricity/data/state/ (accessed 8/9/16).

U.S. Energy Information Administration, 2016. Nevada Electricity Profile 2014. https://www.eia.gov/electricity/state/nevada/ (accessed 10/4/16).

Wildermuth, A. J., 2010. Is Environmental Law a Barrier to Emerging Alternative Energy Sources? Idaho Law Review 46, 509-544.

Wiser, R. H., Pickle, S. J., 1998. Financing Investments in Renewable Energy: The Impacts of Policy Design, Renewable \& Sustainable Energy Review 2, 361. 